\title{
PET Regimen
}

National Cancer Institute

\section{Source}

National Cancer Institute. PET Regimen. NCI Thesaurus. Code C63384.

A regimen consisting of cisplatin, etoposide and paclitaxel used for the treatment of extensive-stage small cell lung cancer. 